\title{
Conceptual Framework Performance Contributor from Internal Organizations of Corporate Social Responsibility Activities
}

\author{
Gogor Arif Handiwibowo \\ Department of Technology \\ Management, Institut Teknologi \\ Sepuluh Nopember, JI. Cokroaminoto \\ 12A, Surabaya, Indonesia \\ gogorhandiwibowo@gmail.com \\ Rini Puji Astuti \\ Department of Technology \\ Management, Institut Teknologi \\ Sepuluh Nopember, JI. Cokroaminoto \\ 12A, Surabaya, Indonesia \\ Rita Ambarwati \\ Department of Technology \\ Management, Institut Teknologi \\ Sepuluh Nopember, JI. Cokroaminoto \\ $12 \mathrm{~A}$, Surabaya, Indonesia
}

In this 20th century era, the business environment is more demanding that a business organization not only have a profit orientation. However, aspects of the impact on the environment and surrounding communities must also receive adequate attention in line with the increasing quantity and quality of business organizations. The concept of sustainable development is proposed to be a concept that tries to provide a balanced effect between financial performance factors, community welfare factors and environmental sustainability factors. In balancing the three factors above, CSR (Corporate Social Responsibility) activities of business organizations are expected to be the answer to the stigma that business organizations are only looking for profit. This paper will describe several hypotheses as well as a conceptual framework of factors originating from internal business organizations that have an impact on the performance of CSR activities. There are four factors that are proposed to be a hypothesis from the internal organization that must be fulfilled so that CSR activities show their performance. The four factors are fulfilment of human resources, fulfilment of the business organization's strategic vision, fulfilment of operating system implementation, and fulfilment of the business organization's financial capability.

Keywords: Corporate Social Responsibility (CSR), Hypothesis, Conceptual Framework, Internal Organization, Performance

\section{INTRODUCTION}

History reveals that Corporate Social Responsibility (CSR) activities have come a long way in their development and are in line with the underlying business orientation. The emergence of the concept of CSR in several literatures has existed since the Mesopotamian era in the 17th century BC, although in a slightly different context because it is more in the context of fulfilment the needs of military and state funds obtained from business activities. This concept was raised because at that time existing business activities had the objective of the process of collecting wealth for the owner only [1-3].

Several definitions related to CSR activities will be explained in the following explanation. CSR is an expression of business activities in the context of a micro-scale economy as well as a medium in the sustainable development process that provides a balance between economic, social and environmental activities around business organizations located [4]. CSR is the basic concept in which a business organization must be able to pay sufficient attention and be accountable for all impacts of its business activities to all its stakeholders, such as employees, customers, shareholders, suppliers, partners, the community and other stakeholders. CSR is also a reference scale in the company's strategy to conduct business operations ethically and to provide emotional closeness to the surrounding community [1].

There has been a lot of literature trying provide discourse and analysis related to CSR activities. At the beginning, CSR activities discussed more about how CSR became a tool to optimize corporate profits leading to an increase in the welfare of its shareholders. Along with the development of business orientation, there has been a shift in the big business vision where apart from being a form of accountability for business organizations, CSR has become a catalyst for the growth of society and the surrounding environment along with the development of the business itself. With the change in paradigm, it gives rise to a vision of how a business organization can grow in harmony with the development of society and the surrounding environment 
[5].

In the context of enriching the CSR literature, this article has a purpose to present the hypothetical factors and conceptual framework that contributes to the performance CSR activities through deepened a review of the literature from internal business organizations. This study is interesting because the company's internal factors are things that are easier to control and make improvements if deemed lacking. This study try to contribute to the operational and strategic contexts that can be applied by corporate leader and manager to strengthen the factors that impact to the performance of CSR activities.

\section{LITERATURE REVIEW}

\subsection{CSR and Company Benefit}

In general, all activities in a company must have a goal which in the end is expected to increase the company's competitiveness [6]. CSR as an activity within a company is indeed an activity that is deliberately carried out by the company to get certain benefits. Meanwhile, when viewed in terms of general benefits, CSR activities are aimed at the community and the surrounding environment. Some literature has discussed by carrying out activities aimed for the community and the surrounding environment will indirectly increasing the value of the company [7-8].

Several studies have concluded the benefits that companies gain from CSR activities. Benefits obtained by companies can be an increase in corporate value, ability to attract workers, ability to increase employee motivation, ability to attract and retain customers, ability to influence customer perceptions, ability to reduce production costs, increase productivity and as well as guarantees for corporate reputation during the crisis [919].

\subsection{CSR Performance}

CSR studies in the 20th century are growing. Sacchi Management Theory suggest anyway as activities within the company, the performance of CSR activities must be measurable as well [20]. Performance measurement is also very necessary to be elaborated in the context of further operations. Because CSR activities have been considered as strategic activities, the performance of CSR activities has received attention from managers in business organizations, especially so that CSR activities have a sustainable impact [21]. Several institutions in the world put sustainability reporting as the main agenda in measuring CSR performance, thus encouraging managers in business organizations to make an impact on sustainability reporting as a form of CSR activity performance.

Some of the CSR performance guidelines, among others, are published by the Global Reporting Initiative (GRI) regarding sustainability performance reporting guidelines. By prioritizing transparency and accountability in its reporting, the standard sustainability reporting guidelines initiated by GRI have received a good reception and are widely used in business organizations. Another performance guideline is the AA 1000 AS issued by AccountAbility - British Institute. This guideline emphasizes the level of accountability from stakeholders for sustainability and social responsibility that is implemented [20]. The IAASB (International Audit and Assurance Standards Board) also issued ISAE 3000 related to corporate social activities. If we look deeper into each of the reporting standards for CSR activities, it shows that Sacchi Management Theory dominates the philosophical standards of reporting made [20].

\section{HYPOTHESIS \& CONCEPTUAL FRAMEWORK}

\subsection{Proposed Hypothesis}

In relation to CSR performance, it is suspected that there are several variables from inside the organization that contribute the achievement of CSR performance. In this context, internal factor contributors are factors that come from within the organization. This factor is heterogeneous and the impact can vary between companies according to its business environment.

\subsubsection{Fulfilment of Human Resource}

Managers and officers who are given the authority to carry out CSR activities are considered to be factors that strongly support the implementation of CSR activities. Thus, dependence on CSR managers and officers in carrying out CSR activities also determines the performance of CSR. This is realized by business organizations so that the managers and officers of CSR activities also receive sufficient training to have sufficient knowledge in implementing CSR activities. The findings of Shen et al. [25] which proves that the adequacy of knowledge in implementing CSR activities for managers and officers has an impact on CSR performance in the textile industry. The availability of experts in the field of CSR is also directly proportional to the complexity of the problems in implementing CSR activities in the shipping industry [26]. The availability of human resources 
who are quite concerned about CSR activities both at managerial and technical levels in various industrial fields has been revealed by several researchers [27-32]. In the context of the adequacy of human resources will greatly affect the operational patterns of implementing CSR activities.

\section{H1: The Fulfilment of human resources has a positive impact to achieve the CSR performance}

\subsubsection{Fulfilment of Strategic Vision}

From several literatures, it is stated that CSR activities are still not a company concern. After exploring further, one fundamental element is that the philosophy of CSR activities has not been included in the company's vision. The indicator that a company has a high commitment to carry out CSR activities is that the philosophy of CSR values must be contained in the company's vision, mission, goals and objectives [33]. With the inclusion of the philosophy of CSR values in the company's strategic vision, CSR activities carried out can be of high quality [27]. On the other hand, the weak leadership role of a company can be an obstacle to the integration process between CSR activities and other company activities, so that CSR activities seem out of sync with other company activities. Thus, strong leadership is needed in order to be able to integrate CSR activities with other company operational activities [34]. In the operational context, strong leadership will be able to formulate highquality CSR activities, implement these CSR activities and evaluate the CSR activities that have been carried out.

\section{H2: The Fulfilment of strategic vision has a positive impact to achieve the CSR performance}

\subsubsection{Fulfilment of Operating System}

The quality of CSR activities in the field is strongly influenced by operational capabilities in carrying out CSR activities. Through operational capabilities, the vision \& mission of business organizations related to CSR can be transformed into CSR activities that can have the expected impact. However, operational capability is currently facing challenges where social and environmental indicators that are acceptable for businesses are still limited and are highly dependent on existing local values [35]. With different perspectives in the business community in understanding CSR activities, it will be a challenge for the managers and officers of CSR activities to design the implementation of quality CSR activities while managing their operations [36]. The implementation of CSR activities requires some ability to measure the quality of CSR activities such as scale of benefit, operational control, benchmarks for program achievement and monitoring of CSR activities [25, 27, 31, 37-39].

\section{H3: The Fulfilment of the operating system has a positive impact to achieve the CSR performance}

\subsubsection{Fulfilment of Financial Capability}

CSR activities definitely require funding, so financial capability is very important in supporting the implementation of CSR activities. Fulfillment of funding in CSR activities must be carried out and must not be affected by the activities of other companies which can be measured more in return on investment (ROI) on a high and more feasible scale [38]. This is because CSR activities on average are activities that require longterm financing. Along with the long financing process, the impact of CSR activities can often only be felt in the long term [28]. Fulfilling financial needs can be a driving force for the fulfillment of other variables in the process of CSR activities, such as meeting training needs to improve HR competencies so that CSR activities become better [37, 40].

\section{H4: The Fulfilment of financial capability has a positive impact to achieve the CSR performance}

\subsection{Proposed Conceptual Framework}

Figure 1 shows the conceptual framework model developed in this study as a result of the literature review process and hypothesis development that has been carried out.

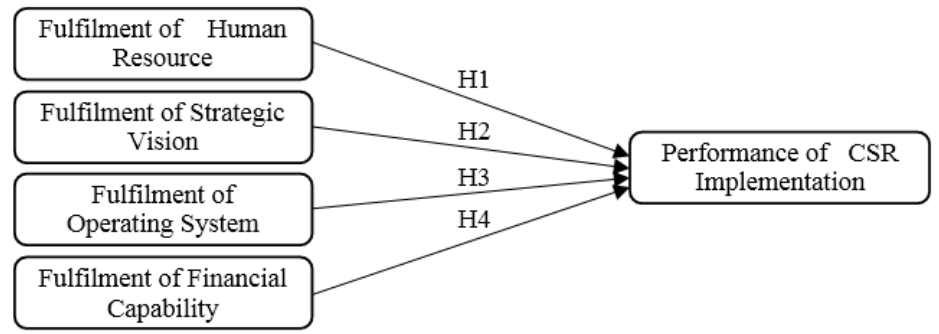

Figure 1: Conceptual Framework which affects CSR performance. 


\section{CONCLUSION}

In accordance with the Sacchi Management Theory, measured activity performance becomes the standard in managing every activity. As one of the activities in the company's activities, CSR activity must also be measured as a form of performance. CSR performance is usually based on the scale of sustainability and its impact on the surrounding community.

Through literature study, it is suspected that there are several factors from the internal organization that play a role in the process of achieving the expected performance in accordance with the implementation of CSR. Internal factors include the fulfilment of human resources, the fulfilment of strategic vision, the fulfilment of the operating system and the fulfilment of financial capacity.

The next step in future research is to empirically prove the proposed hypothesis. Empirical evidence is done by asking the manager \& CSR officers as people who are directly involved in the CSR activities of their respective companies and see the correlation between these variables and the achievement of CSR performance. The results of this empirical test will show quantitatively the respective internal variables of the organization on the achievement of CSR performance.

\section{REFERENCES}

[1] MAIMUNAH, I. (2009). Corporate Social Responsibility and Its Role in Community Development: an International Perspective, the Journal of International Social Research, 2 (9), pp. 199-209.

[2] DANKOVA, P. (2012). Human factor in the CSR, ISBN 978-954-9430-81-3.

[3] NIKOLOVA, V. \& ARSIĆ, S. (2017). The Stakeholder Approach in Corporate Social Responsibility, Engineering Management, 3 (1), pp. 24-35.

[4] SIMEN, S. F., \& NDAO, A. (2013). L'effet de la mise en place d'une stratégie de Responsabilité Sociale de l'entreprise sur la culture organisationnelle: Analyse, implications et enjeux pour le Sénégal. Revue Congolaise de Gestion, 17,pp. 131-170.

[5] GOVINDASAMY, V. \& SURESH, K. (2017). Exploring Approaches to Drivers and Barriers of Corporate Social Responsibility Implementation in Academic Literature, i-COME'16, Kuala Lumpur, Malaysia, September 18-20, 2016, SHS Web of Conferences, Vol. 33, No. 00021.

[6] KANTER, R. M. (1999), From Spare Change to Real Change: The Social Sector as Beta Site for Business Innovation. Harvard Business Review, 77 (3), pp. 123-132.

[7] HANDIWIBOWO, G. (2019). Do Technological Innovation Capabilities Contribute to New Product Development Performance? A Conceptual Framework. https://doi.org/10.4108/eai.30-7-2019.2287608.

[8] HANDIWIBOWO, G. A., NOER, L. R., AMBARWATI, R., \& ARUMSARI, Y. K. (2020). Determining the local community indicators on corporate social responsibilitiy activities (case study in Indonesia). \{IOP\} Conference Series: Earth and Environmental Science, 423, 12017. https://doi.org/10.1088/1755$\underline{1315 / 423 / 1 / 012017}$

[9] HANDIWIBOWO, G. A., NOER, L. R., \& SYAIRUDIN, B. (2019). Collaboration of corporate social responsibility and community development activity for pollution reduction (Case in indonesian power plant csr activities). Pollution Research, 38(2).

[10] BACKHAUS, K.B., STONE, B.A., \& HEINER, K. (2002), Exploring the Relationship between Corporate Social Performance and Employer Attractiveness. Business \& Society, 41 (3), pp. 177-209.

[11] MAIGNAN, I., OC, F. \& TW, H. (1999). Corporate citizenship: cultural antecedents and business benefits. Journal of the Academic of Marketing Science, 26 (4), pp. 455-469.

[12] LUO, X. \& BHATTACHARYA, C. B. (2006). Corporate Social Responsibility, Customer Satisfaction, and Market Value. Journal of Marketing, 70 (October), pp. 1-18.

[13] SEN, S. \& BHATTACHARYA, C. B. (2001). Does Doing Good Always Lead to Doing Better? Consumer Reactions to Corporate Social Responsibility. Journal of Marketing Research, 38 (May), pp. 225-243.

[14] BROWN, T. J., \& DACIN, P. A. (1997). The Company and the Product: Corporate Associations and Consumer Product Responses. Journal of Marketing, 61 (1), pp. 244-249.

[15] HANDELMAN, J. M. \& ARNOLD, S. J. (1999). The role of marketing actions with a social dimension: appeals to the institutional environment. Journal of Marketing, 63 (July), pp. 33-48.

[16] HART, S. L. \& AHUJA, G. (1996). Does It Pay to Be Green? An Empirical Examination of the Relationship between Emission Reduction and Firm Performance. Business Strategy and the 
Environment, 5 (1), pp. 30-37.

[17] MELROSE-WOODMAN, J. \& KVERNDAL, I. (1976). Towards social responsibility: company codes of ethics and practice, Liverpool, British Institute of Management.

[18] PELOZA, J. (2006). Using Corporate Social Responsibility as Insurance for Financial Performance. California Management Review, 48 (2), pp. 52-72.

[19] SCHNIETZ, K.E. \& EPSTEIN, M.J. (2005). Exploring the Financial Value of a Reputation for Corporate Social Responsibility during a Crisis. Corporate Reputation Review, 7 (4), pp. 327-345.

[20] SACCHI, D. (2007). Utilitarian, managerial and relational theories of corporate social responsibility. International Journal of Management Reviews, 9 (4), pp. 347-373.

[21] SPEZIALE, M.T. and KLOVIENE, L. (2014). The Relation between Performance Measurement and Sustainability Reporting: a Literature Review, 19th International Scientific Conference; Economic and Management (ICEM), Riga, Latvia, April 23-25, 2014, pp. 633-638.

[22] BROWN, H., DE JONG, M., and LEVY, D., (2009). Building institutions based on information disclosure: lessons from GRI's sustainability reporting. Journal of Cleaner Production, 17 (4), pp. 571 580 .

[23] ACCOUNT ABILITY (2015). AA 1000 Assurance Standard, AccountAbility, London.

[24] GARCIA-BENAU, A., SIERRA-GARCIA, L., and ZORIO, A. (2013). Financial crisis impact on sustainability reporting. Management Decision, 51, pp. 1528-1542.

[25] SHEN, L., GOVINDAN, K., \& SHANKAR, M. (2015). Evaluation of Barriers of Corporate Social Responsibility Using Analytical Hierarchy Process under a Fuzzy Environment - A Textile Case, Journal Sustainability, 7, pp. 3493-3514.

[26] DIXON, T., COLANTONIO, A., SHIERS, D., REED, R., WILKINSON, S., \& GALLIMORE, P. (2008). A green profession? A global survey of RICS members and their engagement with the sustainability agenda, Journal of Property Investment and Finance, 26 (6), pp. 460-481.

[27] YUEN, K.F., \& LIM, J.M. (2016). Barrier to the Implementation of Strategic Corporate Social Responsibility in Shipping, The Asian Journal of Shipping and Logistics, 31 (1), pp. 49-57.

[28] SKOULOUDIS, A., EVANGELINOS, K., \& NIKOLAOU, I. (2011). An overview of corporate social responsibility in Greece: perceptions, developments and barriers to overcome, Business Ethics: A European Review, 20 (2), pp. 205-226.

[29] BASKARAN, V., NACHIAPPAN, S., \& RAHMAN, S. (2011). Supplier assessment based on corporate social responsibility criteria in Indian automotive and textile industry sectors. International Journal of Sustainable Engineering, 4, pp. 359-369.

[30] VALMOHAMMADI, C. (2011). Investigating corporate social responsibility practices in Iranian organizations: An ISO 26000 perspective. Business Strategy Series, 12, pp. 257-263.

[31] DUARTE, F.P., \& RAHMAN, S. (2010). Perceptions of corporate social responsibility by Bangladeshi managers: An exploratory study. International Review of Business Research Paper, 6, pp. 119-136.

[32] BATTAGLIA, M., BIANCHI, L., FREY, M., \& IRALDO, F. (2010). An innovative model to promote CSR among SMEs operating in industrial clusters: Evidence from an EU project. Corp. Soc. Responsib. Environmental Management, 17, pp. 133-141.

[33] HUSTED, B.W. (2003). Governance choices for corporate social responsibility: to contribute, collaborate or internalize?, Long Range Planning, 36 (5), pp. 481-498.

[34] LAUDAL, T. (2011). Drivers \& barriers of CSR and the size and internationalization of firms. Social Responsibility Journal, 7 (2), pp. 234-256.

[35] JENKINS, H., \& YAKOVLEVA, N. (2006). Corporate Social Responsibility in Mining Industry: Exploring Trends in Social and Environmental Disclosure. Journal of Cleaner Production, 14, pp. 271 284.

[36] PAWLIK, T., GAFFRON, P., DEWES, P., SONG, D., \& PANAYIDES, P. (2012). Corporate social responsibility in maritime logistics, Maritime Logistics: Contemporary Issues, pp. 205-226.

[37] AREVALO, J.A. \& ARAVIND, D. (2011). Corporate social responsibility practices in India: Approach, drivers, and barriers. Corporate Governance, 11, pp. 399-414.

[38] FAISAL, M.N. (2010). Analyzing the barriers to corporate social responsibility in supply chains: An interpretive structural modelling approach. International Journal of Logistic Research Application, 13, 
pp. 179-195.

[39] HARGETT, T.R., \& WILLIAMS, M.F. (2009). Wilh. Wilhelmsen shipping company: moving from CSR tradition to CSR leadership. Corporate Governance: The International Journal of Business in Society, 9 (1), pp. 73-82.

[40] BALASUBRAMANIAN, N.K., KIMBER, D. \& SIEMENSMA, F. (2005). Emerging opportunities or traditions reinforced? Journal of Corporate Citizenship. 17, pp. 79-92 